\title{
LEGAL AND SOCIAL DISCOURSE OF CHILDREN'S PARTICIPATION IN DECISION-MAKING IN POLAND AND RUSSIA: COMPARATIVE ANALYSIS
}

\author{
ALEXANDRA FILIPOVA ${ }^{1}$ \& KRYSTYNA HELAND-KURZAK ${ }^{2}$ \\ ${ }^{1}$ Vladivostok State University of Economics and Service, Complex Research Laboratory for Study of \\ Childhood, 690014, Gogolya st. 41, Vladivostok, Russian Federation. ORCID: 0000-0002-7475-1961, \\ Email: Alexgen77@list.ru \\ ${ }^{2}$ The Maria Grzegorzewska University, Department of Pedagogy, Szczesliwicka 40, room 3411, 02-353 \\ Warsaw, Poland. ORCID: 0000-0002-6130-4644, Email: kheland@aps.edu.pl
}

ABSTRACT: This article draws attention to online discourse of children's participation in decision-making. The participation of children is located in one of the core principles of the Convention on the Rights of the Child (CRC). This study examines the right of the child to express his/her opinion and the participation of the child in matters affecting his/her interests. This paper aims to compare Poland and Russia results in the search process in the Google global search engine, level from 2004 to 2019 using Google Trends. We discover that there are connecting discourses among legal policies in Poland and Russia. There are also differences between clusters of arguments about existence of children's rights in practice.

KEYWORDS: children's participation, children's right, Convention on the Rights of the Child, decision-making, discourse analyses, 'new' sociology of childhood

\section{INTRODUCTION}

We understand the idea of participation as expressed in the Convention on the Rights of the Child, which sets out the right of the child to express her or his views freely in all matters affecting its life, the views of the child being given due weight (article 12). Participation should become a continuous process with no visible end to it. It is about 
helping to create an environment where people (adults and children) can effectively identify and address their own needs" (Okam 2008: 148). It should be noted that children - like adults - are people who have their own worries, aspirations and priorities" (Jarosz 2018). Participation as a concept is about creating platform that levels the binaries of power for inclusivity, through the social positioning of all as humans in search of the good of their society whether as a receiver or capability provider (Okam 2019: 91). The basic problems in the reflection of the sense of participation of children in decision-making are the child's development opportunities and their competences (Phillips 2011). Lansdown situated children's decision-making in the terms of the four elements (2005): (a) ability to understand and communicate relevant information; (b) ability to think and choose with some degree of independence; (c) ability to assess the potential for benefit, risk, and harm; (d) achievement of a fairly stable set of values. Harry Shier, going closer to the children, indicates that participation consists of five elements: "1. children are listened to. 2. Children are supported in expressing their views. 3. Children's view are taken into account. 4. Children are involved in decision-making processes. 5 . Children share power and responsibility for decision-making” (2001: 107).

Hart (1999) presents a modified version of Arnstein's "ladder of participation". Hart's ladder includes eight stages of child participation: "manipulation”, "decoration”, "tokenization”, “assigning, but informing”, "consulting and informing”; "adult initiative and shared decision-making with children"; "children's leadership and initiative"; "children's initiative and shared decision-making between children and adults". In this multitude of definitions, the belief in the ability of children to actually influence their lives and others will always remain a fundamental aspect of participation.

Both countries, discussed in the article, were influenced by Communist Party (19451989). In the Soviet Union children were an important part of the population. One of the main slogan was: "All the best for children". But at the same time children were a well-managed part of the population - an object of powerful ideological influence of the state. The child's participation in decision-making was integrated in pioneer organization (Kravchuk 2014). It consisted of some specific activities such as electing of child's asset, doing some daily duties, visiting special meeting. In the middle, all of these activities were educating of young fighters for the cause of the Communist Party of the Soviet Union. As noted by Smolinska-Theiss, in Poland, in the period of the Polish People's Republic, children's need were hidden by mechanism of power and control (2015). However, against this background, care of the child was developed by organized school medical assistance, comprehensive feeding program, support and social assistance for children. At the time the pedagogy school of Janusz Korczak, the idea of Henryk Jordan was developed (Smolińska-Theiss 2015). Childcare is primarily exercised by the family. The rights of the child are enshrined and respected according to the rank in: (1) the Constitution of the Republic of Poland (1997), (2) The Convention on the Rights of the Child (1991), (3) The Family and Guardianship Code (1964), (4) The act on supporting the Family and the System of Foster Care (2011), (5) The act on Care for Children up to the Age of 3 (2011), (6) The Education Act (1991). 
All the above-mentioned legal acts imposed requirements for the respect of children's rights by adults, and are addressed to children, to be able to use them. As Smolińska-Theiss noted, it is primarily for parents and the school to teach children their rights, especially to speak, to know about themselves, to jointly establish their own plans and solutions with the teacher (2015). In the Russian Federation, there are also some important acts supporting child's rights (1) the Constitution of the Russian Federation (1993), (2) The Convention on the Rights of the Child (1990), (3) The Family Code (1995), (4) The Act "Fundamental Guarantees of the Rights of the Child in the Russian Federation" (1998), (5) The National Strategy for Action in Children's Interests (2012-2017). Chapter 2 of Russian Constitution lists fundamental human and civil rights and freedoms, but only two articles 38 and 39 cover children's protection. The Family Code fixes the child's right to express his/ her opinion (article 57). But it concerns the resolution of family matters affecting him/ her as well as a child can be heard in any judicial or administrative proceedings. Taking into account the opinion of a child who has reached 10 years old is mandatory.

The first document that promoted the idea of child participation in the life of the society in Russia was the National Strategy for Action in Children's Interests. The strategy was in force in 2012-2017. It contained a special section titled "Child Participants of the National Strategy”. Children were referred to as participants in social relations. The section enumerated the main organisational forms contributing to the realisation of the right of the child to express his or her views: children's and young people's civic associations, youth councils, chambers, parliaments and school self-governance bodies.

The position of children's Ombudsman was introduced by decree of the President of the Russian Federation in 2009. Ombudsman appointed to position and dismissed by the President, so the Ombudsman is a part of government. In Poland, the Ombudsman for Children was established in 2000, his position is very high, from 2008 has "hard intervention powers, including the ability to defend the rights of the child in family, civil and administrative courts, on the same rights as the prosecutor, and who received the widest possible control and supervision work with children" (Michalak 2018: 52). In Poland, the most powerful authorities of the $20^{\text {th }}$ century about children's right, is Janusz Korczak, who grew up in Warsaw. Korczak's ideas can be described as a fight for the child's presence in culture, religion, society, and finally the state as a citizens (Odrowąż-Coates and Vucic 2017).

The purpose of our study is to compare Russian and Polish child's rights discourses. Common past of Poland and Russia was influenced by Communist Party ideology. The effects of this influence can be observed now. So our research questions are the following: What are the social and legal discourses of children's right to participate in Russia and Poland? What are their similarities and differences? Who is the main conduit for child's participation discourse?

\section{METHODOLOGY}

The theoretical and methodological framework of the study is set by the "new" sociol- 
ogy of childhood (James, Jenks and Prout 2012; Alanen 1992, Qvortrup 1987), which involves re-opening the world of childhood, addressing children as actors actively transforming social reality, including those affecting the world of adults. This requires the rejection of the previous attitudes of considering children from the position of formation-as objects of socialising influence of adults. A new view of childhood is related to its study "here and now". A child is the same social life's participant as have an adult. The child has the same rights to health, life, an identity, equality, an opinion, education, and free time.

Data were collected using Google search requiers, that is certain word combinations - "child's right to express his/her own opinion" and "the participation of the child in matters affecting his/her interests". The first 10 results for each request in Poland and Russia are analysed. Finally, we have 40 internet-pages with the abovementioned word combinations. The selection of the first ten results of the Google search query is related to the textual and non-textual characteristics of the top 10 . The text criterion means that the contents of the Internet page most fully correspond to the search query (the quality of the text is evaluated). Non-text criterion-evaluation of external reference profile (accounting for the number of references to a resource, assessment of authority of referencing resources, verification of registrations in site catalogs). Also, we used Google Trends as a tool to provide a timeseries index of the volume of queries users enter in to Google in a Poland and Russia area. It allows us to study searching requires by users from different countries for different periods of time, not earlier than 2004. We used the following word combinations: "child's rights" + "children's rights" + "child's rights in Russia/ Poland".

To interpret the collected data, we used discourse analysis, that is interactions between text and context (Fairclough 2003). There are mixture of different d-discourses (Gee 2011) inside this child's right approach - legislative, scientific, public, and others. Legislative d-discourse is created by Polish and Russian legal systems, public (social) discourse - more due to media influence (Becker and Stalder 2009). D-discourses are researched with the help of Google search engine. Nowadays, social media (including Internet) produces new knowledge, experience and discourse. And users play a significant role in the design of this discourse through their searches.

\section{RESULTS AND DISSCUSION}

\section{CHILD'S RIGHTS IN POLAND AND RUSSIA - RESULTS FROM GOOGLE TRENDS}

Firstly, Google trends is used to understand how interested users in Poland and in Russian Federation in the topic of child's right. To build diagrams, we used the same words combination in Russian and in Polish. They are «праваребенка» + «правадетей» + «праваребенка РФ»/prawadziecka+jakiesąprawadziecka+prawadziecka w Polsce (that is "child's rights" + "children's rights" + "child's rights in RF - Russian Federation and in Poland"). 


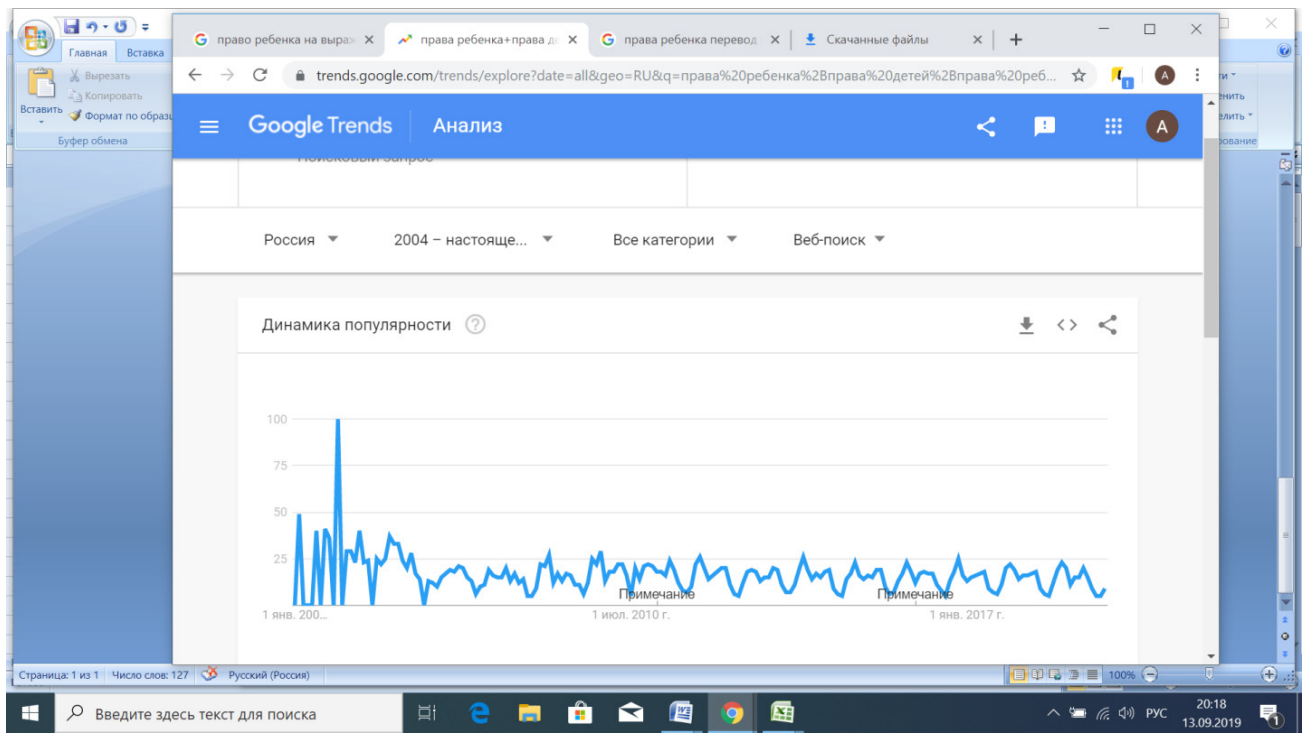

Picture 1 - Dynamics of Google search requires in Russia

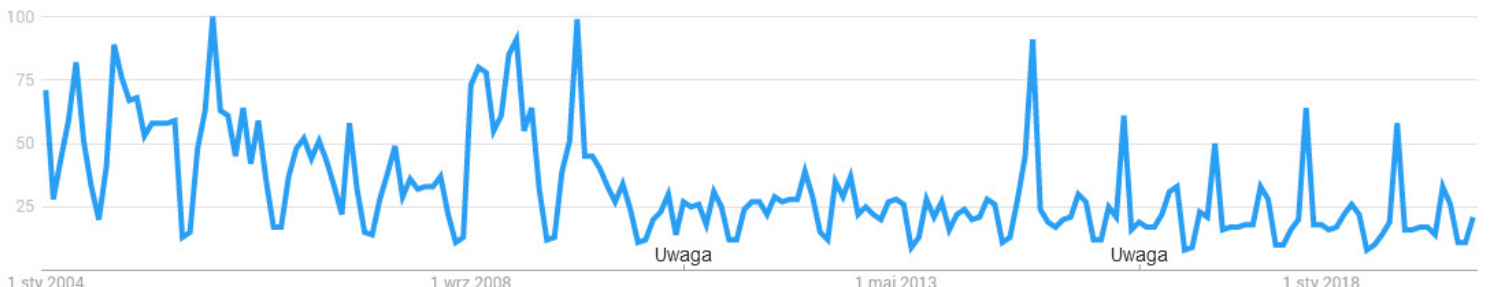

Picture 2 - Dynamics of Google search requires in Poland

In Russia, a rising of user attention occurred in the early 2000s due to a number of changes in the Russian practice of protecting children. In 1998, the Act "Fundamental Guarantees of the Rights of the Child in the Russian Federation" was adopted; in 1999 the post of Children's Ombudsman was introduced. It is strange that the the National Strategy for Action in Children's Interests did not increase user-attention to the topic of children's rights. In Poland, the interest in children's rights was quite stable during the same period without strong ups and downs.

With the help of Google trend tool the most popular searching requires next to 
"child's rights" + "children's rights" + "child's rights in RF / Poland" were found. Comparison showed specific words combination for each country. For Poland, they are (1) "children's rights scenario classes" and (2) “child's rights Korczak". In the first case, the authors speculate that teachers were searching ready-made scenarios for teaching children about children's rights. The second case indicates a very popular interest in Janusz Korczak on the Polish arena. For Russia, they are "protection of child's rights" and "underage's rights". In the Russian legislative system, the concept "child" is used by Family Code, but it turns to "Underage" in the Civil and Criminal Code to underline child's incomplete capacity. In the Russian social practice, instead of the use of the European concept "care, "protection" is because of a lot of risks surrounding the child in his/ her daily life.

\section{CHILD'S RIGHT TO EXPRESS HIS/HER OWN OPINION IN POLAND AND RUS- SIA - RESULTS FROM GOOGLE}

We use word combination "child's right to express his/her own opinion" in Google on September 18, 2019 (Poland) and on September 11, 2019 (Russia). There are about 9920000 (Poland) and 8740000 (Russia) results. The time of searching is 0, $44 \mathrm{sec}-$ onds (Poland) and 0, 57 seconds (Russia). We selected first 10 positions and analysed them separately (in sum 20 internet-pages). All entries were considered at the same items: Who is the author? How is he/ she connected with child's rights? What is the child's position (subject or object)? What are social roles of the child (patient, daughter/son, member of a social organisation, etc.)

Data were analysed in the first approximation, deep study of them will require more thorough study of websites of organisations, expert interviews, and among others.

\section{Poland:}

Four (4) pages were applied to opinions and advice, 1 juridical comment, 2 reports, 1 book review, 2 articles from Ombudsman of Children. Most of the presented pages concern opinion-forming analyses on the expression that the child has the right to express her/his opinion, ranging from the choice of the toy by the infant, through the child-patient, to the child-family member. In 5 pages there is a reference to the activities of the Ombudsman for Children, 3 pages are Catolic. Child's right to express his/ her opinion in Poland - the first 10 results from Google - lie on subjective opinion and advice, in most of the family rights. Putting children's right into family right is a wellknown procedure to highlight the child's belongingness to the family (Kulczyk 2016; Melton 1996; Brennan and Noggle 1997).

\section{Russia:}

Four (4) pages were juridical comments, 2 - scientific articles, 2 - juridical consultations, 2 had link with the same site of CRIN (Child Rights International Network). The most pages had extraction from the Family Code, mainly article 57 "child's right to express his/her opinion". According to this article, "The child has the right to express his 
or her opinion when deciding in the family any matter affecting his or her interests, as well as to be heard in any judicial or administrative proceedings. Taking into account the opinion of a child who has reached the age of 10 years is mandatory" (Family Code of Russian Federation 1995). As can be seen from the text, a child has only two legislatively established spheres of his/ her opinion expressing a family and a court.

What is worth, first of all, we noticed stronger position and stronger influence by child's ombudsman in Poland than in Russia. One link in Russia and four links in Poland are connected with a large number of Ombudsman for Children in Russia (more than 70) instead of one ombudsman in Poland. Secondly, Polish publications are more practically oriented, they have some recommendation for parents, children and educators. While Russian publications set a framework for child participation in the form of legal norms, they do not contain practices of participation, and mechanisms of participation. Thirdly, it is interesting to compare sphere of child's participation and other supporting organisations in these two countries. In Poland, the Catholic Church website is an important participant of child's right realization. In the Russian Federation the legal discourse dominates; thus, child's participation is a participation in the court.

\section{THE PARTICIPATION OF THE CHILD IN MATTERS AFFECTING HER/ HIS IN- TERESTS - RESULTS FROM GOOGLE}

We used word combination "the participation of the child in matters affecting his/ her interests" in Google on September 28, 2019 (Poland) and October 1, 2019 (Russia). There are about 845000 (Poland) and 2320000 (Russia) results. The time of searching is 0,48 seconds (Poland) and 0,55 (Russia). We selected first 10 positions and analysed them separately (in sum 20 internet-pages).

\section{Poland:}

Four (4) pages were a direct link to full books ( 2 were scientific, 2 were guidance books), 3 pages were a kind of juridical comments, 2 were scientific articles, and 1 training material. It is worth noting that all pages of this search set professional standards of legal protection, proper care in the case of children's participation of the matters affecting her/his interests. Most of the discussions about participation of the child in these ten results - are centered in the context of court decisions about children upbringing. However, in Poland - in this background - parents are always responsible in the first instance to allow children the right of participation in matters affecting them. In modern world, it is important to stress that children's needs are crucial, because investing in children means investing in the future society (James and James 2012; Ben-Arieh 2008). The participation of the child also exists in recent studies of Children’s Well-being (Strózik, Strózik and Szwarc 2015) 


\section{Russia:}

From the beginning, it is necessary to note the assignment of three results in search of two words combinations "child's right to express his/her own opinion" and "the participation of the child in matters affecting his/her interests". They were 1 scientific article "Problems of realization of the right of the child to express his (her) opinion", 1 juridical consultation of the Site for Russian parents, Heading "For parents" and 1 juridical comment to the article 57 "child's right to express his/her opinion". Such coincidence on the one hand means the sense proximity of two search phrases, and on the other hand, the incomplete meaning of the phrase associated with participation.

In whole, 8 pages were juridical comments. They were prepared by different legal services including Consultant plus - Russian legal-reference constantly updated system includes more than 1.9 million documents. Sometimes there were links with reviews of judicial practices, the decisions of the Plenum of the Supreme Court, Civil Procedural Code. And 2 pages were scientific articles designating two periods of exercise of the right to participate - before and after 1995. In 1995, Family Code of Russian Federation was accepted.

Comparing the results of the second search query in Poland and Russia, it can be seen that there were coincidences in the appeal to the court as a platform for the participation of the child. At the same time, polish pages were practically oriented including court proceedings and standards. In Poland, the most powerful foundation towards protecting children is "Empowering Children Foundation", studies show that every third child in Poland is a victim of violence by close adults (Wlodarczyk 2017).

\section{CONCLUSION}

It is necessary to distinguish two different levels of children's participation. The first level is related to the expression of children's opinion, and the second level is related to the expression of children's views in decision-making. According to Harry Shier, at the first level children are listened to and supported in expressing their views. And at the second level, children are involved in decision-making processes. The first level is more expressed by legal discourse, the second - by social (public) discourse. The second level is more undefined with non-anchored practices. Legal discourse dominates in Russia. It is based on the article 57 of the Family Code. It concerns the consideration of the child's views in family disputes, especially at the courts. However court reviews show that courts are reluctant to give children the opportunity to express their views.

In Poland the first level is well organised, but as for the second level it lacks real practices of children's including in the decision-making. But in comparison with Russian situation in Poland there are a lot of educational and methodical literature (manuals, practical guides) to help adult hear children's voices.

Research showed that, in Poland there two main defenders of child's rights, including the right to participate: children's Ombudsman and Catholic associations and foundations. They have special recourses and carry out educational activities. In Russia the discourse of children's participation shifted to the rights of children of social 
exclusion - orphans, offenders. So the main child's defenders are guardianship authorities, prosecutor and federal or regional Ombudsmen. But child's right to participate remains beyond their daily activities.

FUNDING: The reported study was funded by Russian Foundation for Basic Research, project № 19011-00654.

CONFLICT OF INTEREST: The authors declare no conflict of interest.

\section{REFERENCES}

Becker, Konrad and Felix Stalder. 2009. Deep Search: The Politics of Search Beyond Google. Innsbruck: Studien Verlag.

Ben-Arieh, Asher. 2008. “The Child Indicators Movement: Past, Present, and Future.” Child Indicators Research 1(1): 3-16. doi: 10.1007/s12187-007-9003-1.

Brennan, Samantha and Robert Noggle. 1997. "The Moral Status of Children: Children's Rights, Parents' Rights, and Family Justice.” Social Theory and Practice 23(1): 1-26.

Fairclough, Norman. 2003. Analysing Discourse: Textual Analysis for Social Research. London and New York: Routledge.

Gee, James P. 2011. How to do discourse analysis: A tool kit. New York: Routledge.

Hart, Roger A. 1999. Children's Participation: From tokenism to citizenship. Florence: UNICEF International Child Development Centre.

Hillis, Ken, Michael Petit and Kylie Jarrett. 2012. Google and the Culture of Search. New York: Routledge.

James, Allison and Adrian L. James. 2012. Key concepts in childhood studies (2nd ed.). London: SAGE Publications Ltd.

James, Allison, Chris Jenks and Alan Prout. 1998. Theorizing Childhood. New York: Teachers College Press.

Jarosz, Ewa. 2018. "Social Participation of Children - A Study in Interdisciplinary Discourse Development.” Pp. 284-303 in The Rights of the Child Yesterday, Today, Tommorow-the Korczak Perspective. Part II, edited by M. Michalak. Warsaw: Office of the Ombudsman for Children-Poland.

Kravchuk, Natalya. 2014. "The child's right to express his / herviews in the Context of Russian culture and democracy.” Russian Law Journal 2(3): 23-48. https://doi. org/10.17589/2309-8678-2014-2-3-23-48

Kulczyk, Marcin. 2016. "Family rights and family policy in Poland.” Torun Social Science Review 1(1): 26-44.

Lansdown, Gerison. 2005. The evolving capacities of the child. Florence: The Unicef Innocenti Research Centre.

Melton, Gary B. 1996. “The child's right to a family environment: Why children's rights and family values are compatible.” American Psychologist 51(12): 12341238. https://doi.org/10.1037/0003-066X.51.12.1234

Michalak, Marek. 2018. “We Have to Fight for Children’s Rights - Korczak’s Pedagog- 
ical Ideas from the Point of View of the Ombudsman for Children.” Pp. 30-89 in The Rights of the Child Yesterday, Today, Tommorow-the Korczak Perspective. Part I, edited by M. Michalak. Warsaw: Office of the Ombudsman for Children-Poland. Odrowąż-Coates, Anna and Basia Vucic. 2017. “The Infant, Early Childhood Development and Child Rights: Re-awakening Opportunities for Social Pedagogy.” Pedagogika społeczna 2(64): 33-55.

Okam, Chinyere L. 2019. "Skolombo and their Continued Existence: Revisiting Lost Humanism and Parentification Impulse.” Society Register 3(4) 75-96. https://doi. org/10.14746/sr.2019.3.4.05

Okam, Chinyere L. 2008. "Pathways to Sustainability: Theatre in the Service of Development." Zaria Journal of Liberal Arts (ZAJOLA) 2(2): 145-153.

Phillips, Louise. 2011. "Possibilities and Quandaries for Young Children's Active Citizenship.” Early Education and Development 22(5): 778-794. https://doi.org/10.10 $\underline{80 / 10409289.2011 .597375}$

Qvortrup, Jens. 1987. “The Sociology of Childhood. Introduction.” International Journal of Sociology 17(3): 3-37.

Shier, Harry. 2001. "Pathways to participation: Openings, opportunities and obligations." Children \&Society 15(2):107-117. https://doi.org/10.1002/chi.617

Smolińska-Theiss, Barbara. 2015. „Funkcja opiekuńczo-wychowawcza szkoły - relikt przeszłości czy współczesne wyzwanie.” Pedagogika Społeczna 3(57): 127-145.

Strózik, Dorota, Tomasz Strózik and Krzysztof Szwarc. 2016. “The Subjective Well-Being of School Children. The First Findings from the Children's Worlds Study in Poland." Child Indicatiors Research 9(1): 39-50. https://doi.org/10.1007/s12187$\underline{015-9312-8}$

Wlodarczyk, Joanna. 2017. „Przemoc wobec dzieci”. Dziecko krzywdzone. Teoria, badania, praktyka 16(1): 192-213.

\section{BIOGRAPHICAL NOTE}

Alexandra Filipova, $\mathrm{PhD}$, is professor at the Far Eastern Federal University and researcher at the Complex Research Laboratory for Study of Childhood at Vladivostok State University of Economics and Service, in Russian Federation.

Krystyna Heland-Kurzak is assistant professor in the Department of Social Pedagogy at The Maria Grzegorzewska University, Poland. Her interests lie in children's development in the early years, and early childhood education.

OPEN ACCESS: This article is distributed under the terms of the Creative Commons Attribution Non-commercial License (CC BY-NC 4.0) which permits any non-commercial use, and reproduction in any medium, provided the original author(s) and source are credited. 